\title{
PREVENTIVE COUNSELING: A RELIGIOUS DEVELOPMENT PROGRAM AT BOARDING SCHOOL IN YOGYAKARTA
}

\author{
Siti Bahiroh ${ }^{1}$, Fitriah M. Suud ${ }^{2 *}$ \\ ${ }^{1,2}$ Lecturer at Universitas Muhammadiyah Yogyakarta, Indonesia. \\ Email: ${ }^{1}$ bahiroh@umy.ac.id, ${ }^{2 *}$ fitriahmsuud@gmail.com
}

Article History: Received on $17^{\text {th }}$ February 2020, Revised on $30^{\text {th }}$ March 2020, Published on $20^{\text {th }}$ April 2020

\begin{abstract}
Purpose of the study: This study aims to explore religious development programs in boarding schools in Yogyakarta and to find out how the implementation of religious development programs, especially preventive counseling programs.

Methodology: This study used a qualitative method with a case study approach. Data collection used observation, interviews, and documentation. The subject were religion teachers, counseling teachers, the vice-principal of student affairs, homeroom teachers, students, and parents of the student.

Main Findings: The results showed that there are two religious development programs at boarding schools in Yogyakarta. First, the development of faith and piety towards Allah by providing concepts in the form of a school lesson. Second, a program to teach religious morals values by internalizing religious values about morals. At the beginning of the study, these programs were designed by paying attention to many current teenage issues and anticipating their future.
\end{abstract}

Applications of this study: This study can be useful in the field of educational psychology, especially in the personality section. The results of this study can be used by counselors at a school to overcome adolescent problems.

Novelty/Originality of this study: This research showed that to make a student well behave in this digital age was not enough if only giving a theoretical study to them but also inviting them to do good things to their teacher. Furthermore, a stay program in the boarding school can be a consideration for parents to form a positive personality for their children.

Keywords: Guidance and Counseling, Spiritual Guidance, Counseling Preventive, Religious Developmental Program.

\section{INTRODUCTION}

Guiding is a human effort to guide and to direct the personality and abilities of children in both formal and non-formal educational institutions (Arifin, M (2008). Previous research related to religious education shows that the model of religious education in pre-prosperous Muslim families uses two models, the mechanical model and the organic model (Egizii, 2015), with four methods, andragogy, role model, motivation, and raising awareness (Zainuddin, 2014). Religious education in formal educational institutions is part of student education, as stated in the Minister of National Education Regulation no.39 of 2008, with educational materials including faith and piety to God Almighty, building good and noble character, excellent personal guiding, and others.

According to the Indonesia dictionary, pattern means pictures, examples, and models. Guiding is an effort of actions and activities carried out efficiently in order to obtain good results. (Ministry of National Education, 2008). Furthermore, Arifin (Arifin, 2008) explained that education is a conscious human effort to guide and direct the personality and abilities of children, both informal and non-formal educational institutions. Thus, the education pattern is a model of activities that carry out by educational institutions or schools to guide and direct the personality (Loudová\&Lasek, 2015) and abilities of students.

Per under Minister of National Education Regulation no. 39 of 2008 concerning student education, student education in school, is the responsibility of the school principal. The learning material, includes: a) Education of faith and piety to God Almighty, b) Education of good character or noble character, c) Education of excellent personality, nationality insight, and national defense, d) Education of academic achievement, art, and sports according to talent and interest, e) Education about democracy, human rights, political education, environment, social sensitivity and tolerance in the context of a plural society, f) Education of creativity, skills, and entrepreneurship, g) Education of physical quality, health, and nutrition, h) Education of literature and culture, i) Education of information and communication technology (ICT), and j) Development of communication in English (RP, 2008). Various kinds of educational materials expect to be able to achieve educational goals, students who believe in and fear God Almighty, noble, healthy, knowledgeable, capable, creative, independent, and student who becomes a democratic and responsible citizen. Each school can develop the education taught in the school based on its vision and mission even though the attachment of the Minister of National Education Regulation No. 39 of 2008 has described the types of activities in education.

\section{LITERATURE REVIEW}

Efforts of guiding students in schools (Nor, Yaacob, and Mohammad, 2019), usually carried out in groups and individuals. Education in groups was generally carried out classically or in groups (Zarei, Fini, and Fini, 2010). The person who provided education can be teachers, school principals, homeroom teachers, or someone who has invited to the school from other institutions, such as the police that carried out mental training education. Other examples were 
religious education carried out by religious teachers or counseling teachers (Zhai, 2019), or the school also could invite spiritual teachers from outside of the school during the celebration of religious holidays. Doctors in health clinics did health education or counseling about drugs. Private individual education (Hursen, 2011), carried out by the counseling teacher (Carroll-Alfano, 2019). Matters relating to personal issues and delinquency became the task of the counseling teacher.

In Indonesia, education and counsel services focused on the younger generation who are still studying in school (Fitri, Hidayat, \& Hartati, 2019). Educational activities that manifested in the form of organized and planned education programs were the most developed educational activities in junior high schools and senior high schools. The resolution of problems that generally arise during adolescence (15-20 years old) would have a significant impact on happiness in their adulthood (Hillard, 2019; Ramos et al., 2017). Thus, educational services for adolescents who were still studying in school would create broad opportunities to guide them so that their personality development is optimal (WSWinkel \& Hastuti, 2013).

Considering the importance of education through education services at this school-age, religious-based educational institutions, especially in senior high school $\mathrm{X}$ and senior high school $\mathrm{Y}$, conducted religious education with various models. Religious education in Islamic based schools was generally programmed and integrated into the curriculum. But in its development, this religious education adjusted to the needs of students. Related to this education service, Edward C. Glanz'sanalyzed his book Foundations and Principles of Guidance (1964) and cited by Winkel. Based on his book, there were four primary models in the history of the development of educational services in educational institutions. First, the generalist model of the belief that the style of education in an institution influenced the quality and quantity of student learning efforts, and all teaching staff could contribute to the student personality development. This illustrated that education services were widespread because all educators were involved. The teachers could insert various elements of education in the lesson. The counseling teacher as mentioned above was the coordinator of the entire guidance and counseling program (Tudor \&Viljoen, 2018).

The counseling teacher as mentioned above was the coordinator of the entire guidance and counseling program (Tudor \&Viljoen, 2018). Second, the specialist pattern believed that the guidance service in educational institutions was handled by educational experts who have special abilities in their fields, such as psychological testing, career guidance, and counseling. The consequence of this pattern was that schools must provide officers with expertise in services such as nurses, doctors, school psychologists, psychiatrists, and social workers. Third, the curricular pattern believed that guidance activities in educational institutions included in the teaching curriculum. It could be in the form of guidance courses with specific material topics such as self-concept (Brabcová, Zárubová, Kohout, Jost, \& Kršek, 2015), individual differences (Baumeister \& Vohs, 2018), motivation and learning, social and cultural factors in personality development (Han, Huang, \& Tang, 2020), life values, and life attitudes. Participants in this course were rated the same as other subjects, so they must pursued the goal of getting grades. Fourth, the relationship pattern of human relations and mental health believed that people will live happier if they can maintain their mental health and foster good relations with others. The implementation of this pattern could form groups that were guided by teachers and guidance staff (CarrollAlfano, 2019). Despite the development of guidance services in educational institutions divided into four basic patterns, educational institutions were different from each other in developing the organizational design of guidance. They allowed an institution to carry out guidance for the students using various models of implementation of the direction to another, depending on the beliefs and tendencies institutions. Besides the identification of problem learners, they also needed to be considered in carrying out the development of students.

Some kinds of problems that often occur to students were (1) facing a time of crisis; due to school failure, failure of young people's relationships, or consuming drugs, (2) difficulties in dealing with self-understanding and the environment, the problem in decision making in career, academic, and social relations, (3) difficulties in preventing promiscuity, (4) difficulties in sustaining students' personalities, which are the development of independence, selfconfidence, self-image, career, and academic development (AT, 1992). Based on the problems faced by students in schools to anticipate the emergence of these problems, Winkel (Hastuti, 2013) explained that the occurrence of democratization in the field of education, students from various backgrounds and tribes who meet each other in the same school would face difficulties to understand each other and accept.

Students faced problems such as; lack of motivation to study, the choice of majors that are not good, low achievement, difficulties in managing time, relationships with teachers are not good, and others. Furthermore, there were also problems that came from family, such as divorce parents, difficult family economics, parents less attention to children's learning, and so forth. Peer association and struggle within himself was also a problem for students (Hastuti, 2013). Student problems varied with conditions and backgrounds. It was necessary to develop a good guiding model to prevent the emergence of problems, to solve problems that students have, and also to maintain the stability of student conditions and keep the conditions good to make students have better improvement. Islamic-based educational institutions (in Senior high school $\mathrm{X}$ and senior high school $\mathrm{Y}$ ) developed a model of religious guidance in anticipating the emergence of problems (student problems). 


\section{METHODOLOGY}

The type of this research was qualitative research with a phenomenological approach. The sampling strategy used purposive sampling; research subjects were not based on the number of people needed to provide information, but whoever was more involved in the implementation of student religious guidance. The main subjects in this study were advisor and counseling teachers, religion teachers, vice principals of student affairs and curriculum, principals, and several students at Senior high school X and Senior high school Y. Research data collection was through observation, interviews, and documentation.

\section{Research procedure}

The researcher conducted research in clear stages. First, the researcher observed the learning situation in some schools in Yogyakarta. The second, the observation was made before reviewing the research proposal and during the study. Some of the things that have observed were the place or space of guiding, religious development activities, the activities of teachers in charge of guiding students, the practice of prayer, and others. Second, the researcher got the permission letter before data collection. Then the researcher discussed the research schedule with the school principal. The researcher gave the schedule for the interview and discussed the right time for the informants to conduct the interview. Then the researcher conducted an interview and observation. The researcher organized In-depth interviews with informants through structured interview models and open interviews. Furthermore, the document was compiled in written and record.

\section{Data analysis}

The data analyzed by the descriptive-analytic method. Data from the field that collected before were grouped based on quality and categories. Furthermore, the data were analyzed and interpreted using inductive and deductive thinking patterns. To analyze the design of student religious formation, researchers used a semiotic approach. Data from field data collected before were grouped based on quality and categories.

To find out the validity of the data or its validity, the researcher used triangulation. After conducted the interviews, the results of the researcher were strengthened with observation. The researcher also confirmed the data from one informant to other informants so that the data collected could be more valid.

\section{RESULTS AND DISCUSSION}

\section{Student Guidance Model in Senior high school X}

The results of interviews conducted with the vice principal of student affairs were that Senior high school X had methods that were typical in the process of guiding piety towards Allah. It meant, by forming a practice of the Islamic boarding school system, the student in the boarding school system were in the school for 24-hour, with academic and religious schedules that programmed. Hopefully, this program could make students become more familiar with spiritual knowledge and could implement the teachings of Islam in their daily life. It was in line with the views expressed by Faturrohman and Sulityorini (SUSIYANI, 2017). He stated that the purpose of education with boarding school method is to build an Islamic generation to have a noble character.

The results of interviews with teachers $\mathrm{S}$, who taught religion subject, mentioned that the boarding school program applied in School X has made significant contributions in shaping the personality of the students. The lesson obtained from the boarding school systemisimportant for the process of forming the personality of students, especially the formation of students' faith and piety to God. The students became more deceived in carrying out daily worship without having to wait for instructions from the teacher.

Furthermore, based on the results of observations conducted in Senior high school X, found that guiding students' faith and piety towards Allah is also done with the routine prayer habituation, such as Duha prayer, Dhuhur prayer, and Asr prayer in congregation. Habituation of daily prayer expected to educate students to be more disciplined in worship, as expressed by the vice-principal of the student affairs.

"The discipline of students in worship is directly proportional to academic achievement and character of their day-to-day. So, we were in school X, have confidence in religious activities that routinely can help students become better, although the results have not seen at this time, we believe they will take the advantage when they graduate from this school (P1)."

The result of the implementation that carried out in Senior high school X conducted by Darini (Darini.2018) showed that the Implementation of the Dhuha Prayer Program in Guiding the Spiritual Attitudes of Students in Senior high school 2 Gunung Jati at Gunung Jati District in Cirebon Regency, brought the change in the attitude of students' spirituality. Student spirituality was getting better. Even though at first, the students practiced worship by force, but the awareness of worship arose gradually because of God (Idrus, M., Ag, M., Alirahman, AD, Muhammadun, S., \& Hanan, 2018). Commemorating Islamic religious holidays was also a routine activity in Senior high school X according to one Islamic religion teacher. The celebration of Islamic holidays such as Eid al-Adha, Maulid of the Prophet, new year hijriyah 
expected to help students in the process of internalizing Islamic values to increase their faith and piety towards God Almighty. Guiding a good character or noble character was the main foundation in the character building of each student (Ulfah KHARITSAH, 2018). One of the main objects in Islamic-based schools was to be able to develop student mentality (DeJonge, Omran, Faulkner, and Sabiston, 2020) in order to become a faithful Indonesian citizen and uphold Islamic moral values in the life of the nation and state. The guiding of the noble character of Senior high school X students has done by teaching a religion subject as one of the lessons in school. First, the subjects were Qur'anic and Hadith subjects. In this subject, the expected learning outcomes were that students will have an understanding of the meaning of the Qur'anic and Hadith verses. Second, the subjects were Aqeedah morals and Arabic. In this subject, the expected outcome was that students have a correct understanding of manners and morals in the association so that they do not fall into promiscuity and superficial aqidah.

The habituation of praying in the congregation also built good or noble character of the student. This program was following the research conducted by Muh. Asroruddin al Jumhuri. The impact of prayer habituation in building spiritualmoral towards fellow humans in the Madrasah Tsanawiyah NW Putra Narmada was that students can apply good attitudes or morals. The good attitudes or morals were the sense of brotherhood that applied through friendship, good manners towards everyone, being honest both in words and deeds, and discipline. The promotion of noble morals also internalized in the monthly prayer activities, which were carried out every two months at the student's house, with the alternating systems according to the agreed schedule. One of the materials in the study is about morals.

In order to conduct personality counseling, excellent personality development carried out the activities of the HW (Hizbul Wathan) scouting activity and Tapak Suci (martial sport). These two activities were mandatory for students. In HW activities, students were given guidance on excellent personality values such as discipline, cohesiveness, creativity, and other aspects. Students were also fostered with a national insight because one of the goals of HW was to strengthen unity and to build a sense of democracy and ukhuwah so that it was useful for religion, homeland, and nation. HW also taught the attitude of defending the state contained in the values of patriotism. Based on Setiawan research, there was information about the natural wealth and culture of Indonesia in Hizbul Wathan lesson (A case study in SMP Muhammadiyah 4 Sambi, Boyolali in the academic year 2013/2014).

A flag ceremony activities carried out routinely every Monday. All students must follow it. Like most schools in general, the students also sang the national anthem of Indonesia led by one of the students. This ceremony used by the school as an opportunity to foster students by the teachers to gain more achievement based on the vision and mission of the school. Senior high school X also held Kartini Day celebrations but still in Muslim clothing style. This ceremony aimed to invite students to have Kartini's compassion for the homeland that has fought for the education of the nation's children so that it became a good quality nation. Furthermore, there was the activity of martial arts called TapakSuci, which was part of extracurricular activities that all the students must follow. The TapakSucimartial arts could build state defense attitude for students. This followed one of the objectives of the TapakSuci. Through the martial arts, TapakSuciencouraged and practiced the amarma'rufnahimunkar in an effort to enhance national resilience. Some specific things to develop the model of guiding conducted by Senior high school $\mathrm{X}$ for personality development wasthrough the Muhammadiyah Student Association (IPM). IPM as an autonomous organization that aimed to form Muslim students who are knowledgeable, noble, and skilled to uphold and uphold the values of Islamic teachings, to realize a truly Islamic society (IPM Article of association 6).

\section{Student Guidance Model in Senior high schoolY}

Based on the results of interviews and observations, Senior high school Y applied the guiding of faith and piety towards God Almighty to their students with various model. First, by adding the contents of some religious subjects in the curriculum, such as the moral creed, Arabic, the Qur'an Hadith, and Islamic history. With various additional components of the content of Islamic religious studies, the students could master the theories of Islamic religion and expected to be able to apply it with a variety of practices and habituation that implemented by the school. Furthermore, the result of the observations showed that students should make the practice of worship in the form of congregational prayers (dzuhur and asar) together at the mosque as a habit [Direct observations at the mosque on April 16, 2019] under teacher supervision. This congregational prayer must be done by all the students, teachers, and employees. According to participant 5, this congregation habituation pattern was:

"Teacher can guide children to practice the religion from the theoretical knowledge they obtained in the classroom, especially for students who have not been praying and guide students who have been praying five times a day in order to remain active. It follows the function of guidance and counseling, involving the function of the understanding, prevention, alleviation, and maintenance and development function"

The teacher also explained that, by carrying out congregational prayers, both students, teachers, and other school residents would add value to the closeness as a school family and also can strengthen the relationship. Furthermore, as an Islamic-based school, Senior high school Y organized Islamic events such as the Prophet's Birthday, Isro' mi'roj, and also sacrificed the sacrificial animals during the Eid al-Adha feast day. In addition to these activities, as a responsibility of the school towards their students in practicing part of the mission to preach, the school taught reading and writing $A l$ - 
Qur'an (Iqro') every Saturday, starts at 8.00 p.m. at the mosque. According to the explanation of the school principal, it was very hard to read and write Qur'an on holiday (Saturday).

"When we decided to have BTA on Saturday, many students protested because Saturday was a holiday for them, but after doing the practice for a month to two months, the children became accustomed and enjoyed the practice. I am very grateful that the graduates of the Muhammadiyah 1 Vocational High School in Bantul can, on average, be able to read the Qur'an, as the main provision in the religious practice."

All students in this school were Muslim. A guiding related to the tolerance between religious communities was carried out with a counseling method or model that conducted during a class delivered by a religious teacher. This prayer program was routinely held by the homeroom teachers, in addition to bonding relationships between students to other students and student to teacher. It was also useful to solve problems related to religious problems (figh of worship and Mu'amalah). According to the homeroom teacher, the gathering event and pray together was very beneficial for students and teachers. The teacher could do a home visit and know how the students' family life is. At the same time, teachers also could hold a conversation related to the development of their children's education with the parent of the student. As an appreciation of Islamic diversity,schools held Islamic-inspired contests in certain events, for example, calligraphy writing and religious quiz competitions in Kartini Day. Besides that, the school also facilitated religious activities through Islamic student organizations. All students became members of Islamic student organizations. There were a lot of social activities that obtained from Islamic student organization activities programs, from cadre events to social service activities. Furthermore, in the context of developing religious activities, the school also organized extracurricular activities of martial arts TapakSuci which all students participate in (the students from grade ten to twelve).

Every school must have a standard system that was made and must be obeyed by all students, teachers, and administrative staff (all school members). Senior high school Y also had rules for students, and all students must obey it. These guidelines have socialized to the students before they started studying at school, but some students violated the rules. This situation was normal. Teenagers tended to violate the rules because they were, as described by Hurlock, in their unstable period. The student wanted a movement by changing in attitudes and behaviors, raising emotions that the intensity goes to the level of physical and psychological changes that occur, and experiencing ambivalent attitudes.

Students must follow the habituation of obeying school rules. It is a way to foster discipline and honesty, which is part of good morals. There were three types of human personality in Islam related to fostering these manners. One of them was a typology of Lawwamah personality. This personality made the person denounce his evil deeds after obtaining the light from the heart. Humans sometimes convinced his hearts and removing the doubts inside his hearts. However, human also sometimes had a bad character, but theNurllahi reminded him, so he repented and asked for forgiveness. In guiding, especially in schools, the good motivation was very important, because good and bad values depend on the power that influenced. Senior high school Y was an Islam basedvocational school, so that all the school members need to do the model of habituation that associated with Islamic religious practice. As one of the counseling teachers said:

"Not manystudent in the school that the parents has religious background. They do not do five times prayer, fasting, do not give charity although they are wealthy.This becomes our concern. An endeavor in the form of habituation that forced students to do prayer is implemented, for example, all student must go to the mosque to do congregational prayers. Participant 8 "

The model of habituation was in line with the opinion of Ibn Maskawaih. He said that character or akhlak, which is the target of character building, was the character that exists in the soul that encourages people to do acts without thinking and considering first, but the act occurs reflexively.Good character building was also carried out through classroom teaching media by providing teaching material with the content of moral guidance. An interview conducted with the ninth-grade student. This was the answer when they were asked about what the class teaching material is.

"Yes ... the material is moral, good manners, the importance of prayer, the ethics of using mobile phones, the society of young people, the endeavors, the ideals, the concerns, the patience ... just like that ... it is not scary things. Which one is scary? "Yes ... it is not like the punishment of hell, the punishment of the grave, or the end of the world ... if it is, then yes, that one is scary." Interviews with students "R,"

In order to foster mutual respect for school members, the school applied a model as an example. The teacher gave examples of mutual respect to fellow teachers, teachers to the principal, and teachers to administrative staff. The teachers also carried out social manners based on Javanese Muslim manners, such as: when meeting each other, we greet and do hand shake and ask for news. Even non-verbally, they empathized with each other by showing facial expressions. Greetings and handshakes also occurred in groups of students every morning when attending school. Greetings and handshakes like this were also applied to groups of students each morning while attending the school. Habituation to students also carried out for generations in terms of sacrifice and family. There was a sample case: when there is someone in school who is sick and stays in the hospital. Other students and the teachers will visit the student who is sick. Other students initiate to give their pocket money and collect pocket money from the rest of the students to buy a gift for the student who is sick, as told by participant 9 . 
The phenomenon of takziyah, or visit the family that one of the members passed away, was also accustomed among teachers and students. Visitation to a family when they are in a bad situation usually done together (in groups and turns). When in mourning, students, especially men, always took part in doing the prayers in congregation, as told by the Mrs Watik when she mourned at her house (Mrs. Watik's husband passed away) in Cepit village, Pendowoharjo. The phenomenon of Vocational high school Y students visiting other student who is sick or in mournful situation and doing charity for the poor people, was in line with Khoiruddin Bashori's writing in the Journal of Education "Menyemai Perilaku Prososial Di Sekolah." The book stated that prosocial behavior was behavior that benefits others, by alleviating physical burdens or psychology, which was conduct voluntarily (sincerely). The key concept in understanding moral development was internalization and changes in the development of behavior that was controlled externally then become internally. This prosocial behavior developed widely in Senior high school Y, as a provision for students to live their lives in the future. Not all Senior high school Y students grew up in a family and community environments that uphold prosocial moral values. There were still many students who were in bad situation family and bad community in developing moral values. As Mr. Harimawan said:

"As a principal of this school, I tried to be able to conduct the values of Islam, especially moral values. Morals to Allah SWT, in the form of worship according to the Rasul's guidance, and the morals of fellow human beings, such as responsibility, independent, honest, respectful, polite, compassionate, caring, cooperation, and creative. Also, I emphasized the morality of the environment, considering that the learning process of students is in contact with objects such as machines and other electronic devices. Children must be able to care for those things properly, use them but also protect the environment." The interview result with the school principal.

Based on this noble character, socialization regarding cleanliness was also carried out with a sentence of "Annadhofatu minal of faith", (keep it clean). Besides through a sentence, cleanliness was also done through practice. The availability of trash bins (for dry trash and wet trash) in certain places was maintained to dispose of waste of food packages, drinks, or any other waste. On certain days, a community service activity (cleaning the school environment) was held. The description showed that the school strives to build a culture based on progressive Islamic values.In order to carry out excellent personality development, character building conducted through scout activities, students visitation to the historical place, and the spirit of defending the country. Senior high school Y conducted cooperation with the Police department to guide students. Furthermore, the flag ceremony is held routinely every Monday, and all students must follow it. As in general, studentssang the national anthem Indonesia led by one of the students. Schools used this ceremony as an opportunity to guide the students to achieve the vision and mission of the school.

Senior high school Y made some specific things to develop a guiding model for the student. For this personality development, the development was through the Islamic Student Association. This was an autonomous organization that aims to form Muslim students who are knowledgeable, noble, and skilled in order to uphold and raise the values of Islamic teachings. Furthermore, there was the activity of Tapak Suci martial art, which is part of extracurricular activities that all students must follow. This Tapak Suci martial art was made to form an excellent Islamic character or personality. The school also held a visitation to the historical places, such as the train museum, mini-park, and Yogyakarta Palace.

Islam taught that competing in goodness (fastabikulkhairat) is a form of worship. The meaning of competing in goodness was that if someone is doing good things to someone else, then he must do better to anyone else again and again, without having to hurt and harm others. Every competition in goodness would undoubtedly have benefits. In vocational schools like Senior high school Y, the application of "fastabikulkhairat" was done through fostering academic achievement, art, and sports. After school, students were expected to be independent or go to work. For the things that related to creativity and art, the model of guiding was to involve students in participating in competitions at the region and province levels. The types of competitions that the students can participate in were speech competitions, student creation competitions, and writing competitions. For the competition in schools, the school held a class meeting (classes sport competition), Javanese culture and Yogyakarta history olympiad.

Related to creativity, Senior high school Y students have succeeded in making flash media to support learning. The results of student creativity (media flesh) [Interview with Sri Kusminah mother, May 12, 2019], used by the teacher for learning purposes. There were exhibitions ofinnovative creation in schools, such as "solar power motors" made by students. Furthermore, to optimize the library, schools could access electronic books. In improving students' academics, the school organized comparative studies and study tours to places that the students can learn, such as visitation to industrial factories that related to each department. This visitation conducted at JABODETABEK (Jakarta, Bogor, Tangerang, and Bekasi city). The sports were also developed by forming a football club and TapakSuci martial art. All students must participate in (integrated with the curriculum) (participant 3).

Student organizations or student council existed in every school, but this organizational activity needed support or motivation from the teacher. The existence of this student organization could be an opportunity for the student to practice leadership. Leadership training could be done through student organizations. In Islamic based schools, this guidance was performed through Islamic Student Association organizations. For the honesty training of students, the school made an "honesty canteen." Furthermore, for the activities of new students academically and introduction to the 
environment, students were directed to positive activities, such as replanting trees programs or practicing a line of march in collaboration with the police.

This study found a model of religious guiding that generally conduct in religious-based schools, by the habituation, good example, and also by integrating religious guidance into the curriculum. The guiding model was generally synchronized to the Minister of National Education Regulation no. 39 of 2008 concerning guiding students in schools is the responsibility of the school principal. However, the teachers in the school also played an essential part in it.Almost all of the ten training materials offered by Ristekdikti can be implemented. There was a development model in the implementation of it, such as conditions and situations of students both internal and external, the ability of the school, and the vision and mission of the school.

For the religious aspect development of students related to fostering faith and piety to God Almighty and building noble characters, both Senior high school X and Senior high school Y used a similar model of development that includes several components of religious subjects such as Arabic language, fiqh of worship, Islamic Cultural History, and others. The students also did habituation of the prayer, such as congregational of five-time prayer and dhuha prayer. Besides that, students commemorated Islamic holidays, such as the birthday of the Prophet (Maulid) and the new year of Hijriyah. These habituation were in line with Darini's research (2018) that thestudent's spirituality attitude increased after carrying out the regular worship of the Duha prayer at school.

Religious guiding activities related to fostering piety towards God Almighty and fostering noble character in Islamicbased educational institutions was a model of preventive counseling (Akers et al., 2014). It was programmatic so that students can develop their potential of religious fitrah optimally, by internalizing Islam values that contains in the holy book of the Al-Qur'an and the sunnah of the Prophet Muhammad. This was following the opinion of Pietrofesa (Pietrofesa, JJ, \& Schlossberg, 1977), who support the efforts of counselors who work with students to understand themselves related to sexual problems and prepare their best to deal with these problems (sexual) in the future (Mappiare, 1992). Thus, activities that were programmatic or designed to be a program for the future needs of students to prevent the emergence of problems in the future was a type of preventive counseling (Curry \& Whitlock, 2015). The purpose of problem prevention was a type of preventive counseling (Krist, Davidson, Ngo-Metzger, \& Mills, 2019). Boarding school model made to guide religious aspects to the students. The school conducted programmatic activity for students, by integrating subject components in the curriculum, familiarizing congregational prayers in mosques, reading and writing al-Qur'an, recitation of religious teachings, a commemoration of Islamic holidays, habituation of prosocial attitudes, and other things else ( $\mathrm{Wu}$, Yuan, and Kou, 2020) .

There was a difference in the character of school between senior high school and vocational high school. It influenced the development model of religious guidance for the student. Senior high school X strived more for how the school can control students continuously so that they can change behavior. After that, the student expected to control their behavior internally (not affected externally). This effort carried out by establishing an Islamic boarding school program, which in its implementation, students were in the school supervision for 24 hours with programmed academic and religious schedules. This boarding program aimed to make students become more familiar with religious knowledge and be able to apply the teachings of Islam in their lives.

Furthermore, vocational high schools expected to enter the workforce after graduation. The model of the development religious guidance for students from the vocational high school conducted by building basic religious aspects for the students. It could be done by requiring the students to read Al-Qur'an and write an Arabic letter. For fostering good and noble character, the vocational school developed more the "competing in goodness" (fastabikul khairat) aspect. If someone else is doing good to anyone, then he must do better again and again to anyone else. It also focused on the development of prosocial moral values (Cardinaels, 2016) to students. This was following an article written by KhoiruddinBashori (Bashori, 2017), that there was a relationship between the development of social behavior with student moral reasoning. Initially, external factors control (Bashori, 2017) the development of the behavior. If there was the internalization of prosocial values, then the behavior can be controlled internally. The vocational high school invited many of their students to practice things like empathy that is applied directly when visiting sick people, sharing that is applied when Eid Al-Adha, accompanying people who need help, and others.

Furthermore, when viewed from the perspective of guidance models (Edward C.Glanz: 1964), both in Senior high school $\mathrm{X}$ and Senior high school Y, religious guidance referred to three models. They were generalist models, specialist models, and curricular models. The style of education in this institution influenced the religious quality of students. All educators involved to guide student learn religious aspect by teaching the values of Islam in the lessons. Religious guidance services at this institution were carried out by religion subject teachers who have special abilities in the religious field. Religious guidance activities integrated into the curriculum of the school.

\section{CONCLUSION}

Deviant behaviors that are increasingly happening now in teenagers became the strong reason why students need spiritual guiding urgently. Ethical guidelines aimed to direct students towards Islamic personalities. The Qur'an and alHadith, as the primary sources of Islam, formed Islamic spiritual character for students. All teachers in Islamic-based 
schools should pay attention to students' personality growth through various religious guidance activities. Efforts have been made at the school to select school leaders who can be role models for all students, teachers, staff, and all members of the school. Further effort was to add the content of religious subjects in the curriculum of the school. Teachers are accustomed to spiritual practices in schools and formed Muslim student organizations. There was a fundamental difference between the two schools studied. The first school conducted moral guidance by opening boarding classes, while the other school used the fastabikulkhairat program (compete in kindness) and developed prosocial values that benefit them and the local community. It was because the other school is a vocational school and they have more project to do after school time end. All activities related to religious guidance were programmatic. It classified as preventing the counseling model if it viewed in terms of handling time and problem-solving processes.

\section{LIMITATION AND STUDY FORWARD}

The researcher conducted this research at an Islamic school. So henceforth, other researchers can do further study at other types of schools. Religious education is more maximal at the boarding school rather than a common regular school because teachers have more time to guide the students. Teachers also can be role models for all students. For schools that are not boarding schools, researchers suggested that teachers make better relations with parents of students. So, parents and teachers can help each other in building students' personality for the students' better future.

\section{ACKNOWLEDGMENT}

The researcher thanks the principal, teachers, students, and parents who helped provide information about this research. The author also thanks co-authors who helped complete this manuscript.

\section{AUTHORS CONTRIBUTION}

The primary author has a more significant task than the second author. First, the lead author looked at the most recent studies and then conducted the current research. Furthermore, She has responsibility for the results of their research. The second author has a focus on how to organize research results in articles that can be published and then transferred into English.

\section{REFERENCES}

1. Akers, AY, Davis, EM, Jackson Foster, LJ, Morrison, P., Sucato, G., Miller, E., \& Lee, MJ (2014). Parental report of receipt of adolescent preventive health counseling services from pediatric providers. Patient Education and Counseling, 94 (2), 269-275. https://doi.org/10.1016/j.pec.2013.10.003

2. Arifin, M. (2008). Reciprocal relationships Jakarta Religious Education. Jakarta: BulanBintang.

3. Bashori, K. (2017). Sowing prosocialbehavior in school. Sukma: Journal of Education, 1 (1), 57-92. https://doi.org/10.32533/01103.2017

4. Baumeister, RF, \&Vohs, KD (2018). Revisiting Our Reappraisal of the (Surprisingly Few) Benefits of High Self-Esteem. Perspectives on Psychological Science: A Journal of the Association for Psychological Science, 13 (2), 137-140. https://doi.org/10.1177/1745691617701185

5. Brabcová, D., Zárubová, J., kohout, J., Jost, J., \&Kršek, P. (2015). Effect of learning disabilities on academic self-concept in children with epilepsy and on their quality of life. Research in Developmental Disabilities, 4546, 120-128. https://doi.org/10.1016/j.ridd.2015.07.018

6. Cardinaels, E. (2016). Earnings benchmarks, information systems, and their impact on the degree of honesty in managerial reporting. Accounting, Organizations and Society, 52, 50-62. https://doi.org/10.1016/j.aos.2015.09.002

7. Carroll-Alfano, MA (2019). Education, counseling, support groups, and provider knowledge of total laryngectomy: The patient's perspective. Journal of Communication Disorders, 82. https://doi.org/10.1016/j.jcomdis.2019.105938

8. Curry, SJ, \& Whitlock, EP (2015). BehavioralCounseling Interventions Expert Forum: Overview and Primer on US Preventive Services Task Force Methods. American Journal of Preventive Medicine, 49 (3), S129-S137. https://doi.org/10.1016/j.amepre.2015.04.017

9. DeJonge, ML, Omran, J. Faulkner, GE, \&Sabiston, CM (2020). University students 'and clinicians' beliefs and attitudes towards physical activity for mental health. Mental Health and Physical Activity, 18, 100316. https://doi.org/10.1016/j.mhpa.2019.100316

10. Ministry of Education. (2008). Indonesia Dictionary. Jakarta: Language Center.

11. Egizii, R. (2015). Self-directed learning, andragogy and the Role of Alumni as Members of Professional Learning Communities in the Post-Secondary Environment. Procedia - Social and Behavioral Sciences, 174, 1740-1749. https://doi.org/10.1016/j.sbspro.2015.01.832

12. Fitri, Hidayat\&Hartati, S. (2019). Program management counseling Junior High School. Counsellia: Journal of Guidance and Counseling, 9 (2), 103. https://doi.org/10.25273/counsellia.v9i2.4808

13. Glanz, EC (1964). Foundations and principles of guidance. Allyn and Bacon.

14. Han, S., Huang, H., \& Tang, Y. (2020). Knowledge of words: An interpretable approach for recognition from social media personality. Knowledge-Based Systems, 105550. https://doi.org/10.1016/j.knosys.2020.105550 
15. Hastuti, W.. W. \& MS (2013). Guidance AndCounseling in Educational Institutions, Yogyakarta. Yogyakarta: Timeless Media.

16. Hillard, PJA (2019, September 1). Practical Tips for Intrauterine Device Counseling, Insertion, and Pain Relief in Adolescents: An Update. Journal of Pediatric and Adolescent Gynecology, Vol. 32, pp. S14-S22. https://doi.org/10.1016/j.jpag.2019.02.121

17. Hursen, C. (2011). Psychological Counseling and Guidance Department's assessment on students learning to learn perception of competence. Procedia - Social and Behavioral Sciences, 30, 2452-2456. https://doi.org/10.1016/j.sbspro.2011.10.478

18. Idrus, M., Ag, M., Alirahman, AD, Muhammadun, S., \& Hanan, HA (2018). Dhuha Prayer Program Implementation in Development Spiritual Attitude of Students at SMPN 2 GunungJatisubdistrictGunungJati Cirebon.

19. Krist, AH, Davidson, KW, Ngo-Metzger, Q., \& Mills, J. (2019). Social Determinants as a Preventive Service: US Preventive Services Task Force Considerations for Research Methods. American Journal of Preventive Medicine, 57 (6), S6-S12. https://doi.org/10.1016/j.amepre.2019.07.013

20. Loudová, I., \&Lasek, J. (2015). Parenting Style and its Influence on the Personal and Moral Development of the Child. Procedia - Social and Behavioral Sciences, 174, 1247-1254. https://doi.org/10.1016/j.sbspro.2015.01.744

21. Mahmudah, S. (2018). Implementation of guidance counseling in MI Assa'adahLabuapi, Labuapi District of West Lombok district in the academic year 2016/2017 (Doctoral dissertation,). State Islamic University of Mataram.

22. Mappiare, A. (1992). Introduction to Counseling and Psychotherapy. Jakarta: Eagles.

23. MhdSarif, S. (2019). STRATEGIC AND FASTABIQUL KHAIRAT TA'AWUN Partnerships FOR SUSTAINABLE COMPETITIVE ADVANTAGE AMONG SMALL AND MEDIUM ENTERPRISES IN THE MUSLIM WORLD. Asian Academy of Management Journal, 24 (1), 125-139. https://doi.org/10.21315/aamj2019.24.s1.9

24. Mujib, A. (2017). Personality theory in psychology Islam. Second printing. Jakarta: RajaGrafindoPersada.

25. Noor, NM, Aaron, J., \&Aris, B. (2012). Andragogy and Pedagogy Learning Model Preference among Undergraduate Students. Procedia - Social and Behavioral Sciences, 56, 673-678. https://doi.org/10.1016/j.sbspro.2012.09.702

26. Nor, ZMZMN, Yaacob, NNM, and Mohammad, JAM (2019). Dimensionality and reliability of USM preclinical medical students' guidance and counseling needs questionnaire. Taibah University Journal of Medical Sciences, 14 (2), 123-130. https://doi.org/10.1016/j.jtumed.2019.01.002

27. PR, I. (2008). MINISTER OF NATIONAL EDUCATION OF THE REPUBLIC OF INDONESIA NUMBER 39 OF 2008 CONCERNING THE PROMOTION Student BY THE GRACE OF GOD THE ALMIGHTY PDF Download Free. Retrieved February 16, 2020, from https://docplayer.info/30675763-Peraturan-menteripendidikan-nasional-republik-indonesia-nomor-39-tahun-2008-tentang-pembinaan-kesiswaan-dengan-rahmattuhan-yang -maha-esa.html

28. Pietrofesa, JJ, \& Schlossberg, NK (1977). Counselor bias and the female occupational role. Sex Bias in the Schools, ed. J. Pottker and A. Fishel Teaneck, NJ: Fairleigh Dickinson. Fairleigh Dickinson University Press.

29. Ramos, MM, McGrath, J., Sebastian, RA, Stumbo, SP, Fairbrother, G., \& Sebastian, RA (2017). Measuring Unmet Needs for Guidance anticipatory Among Adolescents at School-Based Health Centers. Journal of Adolescent Health, 60 (6), 720-726. https://doi.org/10.1016/j.jadohealth.2016.12.021

30. Sari, DPP (2018). ENHANCING THE LEARNING OF ISLAMIC RELIGIOUS EDUCATION SUBJECT MATTER OF CONDUCT OBEY, COMPETITION IN FAVOR AND USE STRATEGY WORK ETHOS Facilitator STUDENT IN CLASS AND Explaining XI SEMESTER SMK PGRI 2 SALATIGA YEAR STUDY 2018/2019.

31. SUSIYANI, USA (2017). BOARDING SCHOOL EDUCATION MANAGEMENT AND EDUCATIONAL PURPOSES relevance to Islam in MUHAMMADIYAH MODERN COTTAGE BOARDING BOARDING SCHOOL (MBS) YOGYAKARTA. Doctoral dissertation, SunanKalijaga State Islamic University.

32. Tudor, K., \&Viljoen, B. (2018). Counseling and psychotherapy of and in the South Pacific. Asia Pacific Journal of Counseling and Psychotherapy, 9 (1), 3-19. https://doi.org/10.1080/21507686.2017.1415944

33. Ulfah KHARITSAH, N. 1323301233. (2018). EDUCATION Morals NOBLE: habituation READING QUR'AN AND AN ORPHANAGE TAHAJUDDI Salah-NADHIEF Senon KEMANGKON DISTRICT DISTRICT PURBALINGGA.

34. WSWinkel, \&Hastuti, MMS (2013). Guidance and counseling Education Institution. Yogyakarta: Timeless Media.

35. Wu, J., Yuan, M., \& Kou, Y. (2020). Disadvantaged early-life experience negatively Predicts prosocial behavior: The roles of Honesty-Humility and dispositional trust among Chinese adolescents. Personality and Individual Differences, 152 (September 2019), 109608. https://doi.org/10.1016/j.paid.2019.109608

36. Zainuddin. (2014). Andragogy IMPLEMENTATION IN BOARDING BOARDING SCHOOL STUDENTS AL-Hikam Malang. Rosidin, Andragogi concept in the Quran touches Islami Adults on Theory and Practice of Adult Education (Malang: LiteraUlulAlbab, 2013), 
Humanities \& Social Sciences Reviews

eISSN: 2395-6518, Vol 8, No 2, 2020, pp 614-623

https://doi.org/10.18510/hssr.2020.8269

37. Zarei, E., Fini, AAS, and Fini, HK (2010). A comparison of the effect of group counseling methods, behavioral, cognitive and cognitive-behaviorall to reduce test anxiety students in the University of Hormozgan. Procedia Social and Behavioral Sciences, 5, 2256-2261. https://doi.org/10.1016/j.sbspro.2010.07.445

38. Zhai, X. (2019). Becoming a teacher in rural areas: How curriculum influences government-contracted preservice physics teachers' motivation. International Journal of Educational Research, 94, 77-89. https://doi.org/10.1016/j.ijer.2018.11.012 